\title{
Three Puzzles in Search of an Answer From Political Scientists (With Apologies to Pirandello)
}

\section{Citation}

Hochschild, Jennifer. 2004. Three puzzles in search of an answer from political scientists (with apologies to Pirandello). PS: Political Science \& Politics 37, no. 2: 225-229.

\section{Published Version}

http://journals.cambridge.org/action/displayAbstract?fromPage=online\&aid=214737

\section{Permanent link}

http://nrs.harvard.edu/urn-3:HUL.InstRepos:3347574

\section{Terms of Use}

This article was downloaded from Harvard University's DASH repository, and is made available under the terms and conditions applicable to Other Posted Material, as set forth at http:// nrs.harvard.edu/urn-3:HUL.InstRepos:dash.current.terms-of-use\#LAA

\section{Share Your Story}

The Harvard community has made this article openly available.

Please share how this access benefits you. Submit a story.

Accessibility 


\section{Three Puzzles in Search of an Answer from Political Scientists (with Apologies to Pirandello)}

Dolitical scientists have paid too little attention to the politics and policy of education in the United States. Most scholars could write an analogous sentence about their own cherished fields of research, but this one is really true. Consider a few facts: social scientists often describe the United States as a welfare laggard compared with similar European nations because it spends relatively less on family support, employment assistance, health insurance, or public child care. But the U.S. has always been a welfare leader in the field of education; here public schooling started much earlier, has always included more people, has until very recently given students more years of education, and has absorbed a larger share of resources. In 2001, it cost about $\$ 390$ billion to educate children in public schools (that does not include higher education or the more than $10 \%$ of $\mathrm{K}-12$ students in private schools or being home-schooled). That is more than our nation spent on defense and not much less than on social security in that year. Almost a quarter of all state expenditures go to K-12 schools, and the 7 million people with part- or full-time jobs in

by Jennifer L. Hochschild, Harvard University schools constitute more than half of all local governmental employees. Public schools are the second largest employer in Los Angeles

County and the largest in Baltimore (the same holds for other cities). ${ }^{1}$

Beyond these figures, but arguably responsible for them, is the unique place that public schooling occupies in the American political and social culture. Europeans believe more strongly that the state should ensure a decent standard of living for all citizens; Americans believe more strongly that the state should provide opportunity, with the citizen then responsible for earning a decent standard of living. And schools are arguably the most important public institution through which Americans have chosen to (at least in theory) provide opportunities, teach the skills needed to succeed, equalize life chances, transmit democratic norms and skills, and bring outsiders into the public arena and mainstream society. For better and for worse, public education is the United States' only shared public arena that can and almost does include all future adults.

It is no surprise, then, that Americans argue intensely over whom to include in public schooling, on what terms, with what resources provided by whom, and for what ends. A central manifestation of this perennial conflict was the era of school desegregation, roughly from 1954 until the early 1990s. This article begins by exploring a puzzle over the dominant interpretation of that era, and continues with explorations of two other puzzles that grow out of the first. All present, to me at least, genuine questions that call for the kind of sophisticated political analysis that members of our profession could provide, but largely have not.

\section{The "Failure" of School Desegregation}

Analysts and advocates, left and right, whites and nonwhites, mostly concur that mandatory desegregation was a massive social experiment that failed. Supreme Court Justice Anthony Kennedy observed once during oral argument that he saw "no advantages to have been brought about by busing." AfricanAmerican mayors in Cleveland, Seattle, Denver, St. Louis, and elsewhere have led battles to end court-ordered desegregation plans.

Politicians can perhaps be understood, even forgiven, for mistaking or exaggerating important facts (although it is noteworthy, and I will return to the point, that most politicians believe their constituents to be more eager to hear about desegregation's apparent failure than about its arguable success). But sophisticated political analysts say the same. Although the sociologist David Armor finds "forced racial segregation" to be "unconstitutional and immoral," he concludes that "it has not been demonstrated that ... desegregated schools by themselves produce consistent social and educational benefits; in some cases, the consequences of desegregation may be harmful to race relations and black self-esteem" (Armor $1995,112)$. From a very different political perspective, Gary Orfield and his colleagues also agree that desegregation is failing - in this case because there is too little rather than too much of it. They ask, "has Martin Luther King's dream become a nightmare?" and answer that it is moving rapidly in that direction (Frankenberg et al. 2003, 7).

Why do both social scientists who would endorse more mandatory desegregation and those who would prefer less (or none) agree that school desegregation is a failure? That general question must be framed slightly 
differently for proponents and opponents. With regard to the former: virtually every child psychologist and education expert agrees that children are more inclined to improve with encouragement than with harsh and disdainful criticism; report cards in grade schools offer only the choices of "excellent," "satisfactory," and "needs improvement." "Failure" is nowhere to be found. Are adults so different, that they are best motivated by an insistence that their quite extraordinary efforts for several decades have come to naught?

With regard to opponents: setting aside those who would prefer race relations to be bad and African Americans to remain in a subordinated position, why do so many conservatives reject school desegregation in favor of more choice-based policies? After all, several decades ago conservatives argued, in the name of coherence and neighborhood solidarity, for policies that assign children to schools near their homes rather than sending them all over the district in scattered and unpatterned directions. Why endorse such a scattershot approach now, rather than place-based schooling?

The question of why most analysts concur that school desegregation has failed is sharpened by the fact that one can make a plausible case that it has succeeded. In 1964, virtually no black children attended school with whites in the south (where three-fifths of African Americans lived). By 1988, the proportion of black students in majority white schools in the south had risen to almost $44 \%$. That figure has since slipped to $31 \%$ - a substantial reversal, but not (yet) a "nightmare." For the nation as a whole, the proportion of black students in "intensely segregated schools" $"$ declined from two-thirds in 1968 to one-third in 1988, and has since risen to $37 \%$ : again, a move in the wrong direction, but not failure. ${ }^{3}$

So desegregation has to some degree worked, in the crude but essential sense of putting more black and white children into the same school buildings than would otherwise have been there. Although all of this can be (and is) contested, the evidence also suggests that desegregation has worked in more substantive ways as well. Economist Jonathan Guryan concludes that "desegregation plans . . . can account for about half of the decline in dropout rates of blacks between 1970 and 1980. . . . [They] had no effect on the dropout rates of whites" (Guryan 2001, abstract). African Americans' achievement test scores improved steadily (and whites' scores did not decline) in reading, math, and science during the 1970s and 1980s, the two decades that black and white students increasingly attended school together-and did not improve during the 1990s, when the amount of racial mixing was partly reversed. Many things happened during this period, of course, so direct causation is very hard to prove (or disprove). The best recent study, however, found that even controlling for family background and prior achievement, blacks' (and Latinos') reading scores are substantially closer to those of whites in integrated elementary schools compared with racially separate ones (Phillips 1998).

School desegregation has also arguably had valuable and important long-term effects. Compared with racially isolated black students, those from desegregated schools have higher job aspirations, do better in college, and are somewhat more likely to hold white-collar and professional private sector jobs. Both black and white students, and later adults, from integrated schools have more close friends and casual acquaintances of the other race than do those from racially isolated schools. ${ }^{4}$ They are more likely to attend desegregated colleges, live in integrated neighborhoods, hold jobs in integrated work settings, and be comfortable in racially-mixed work groups.

Finally, Americans endorse school desegregation, at least in principle. In a 1999 survey, fully $80 \%$ of young adults (who are most likely to have experienced desegregated schools), compared with $63 \%$ of the elderly, agreed that integration "has improved the quality of education received by black students." Across all age groups, as many whites as blacks concurred. Seventy percent of young adults (and 45\%of the elderly) also agreed that it had improved whites' schooling. In this case, however, the races split; a majority of blacks and a minority of whites concurred. Substantial majorities of both races agree that school desegregation has "improved relations between" the races, and by 1995 , fully $96 \%$ of whites agreed that black and white children should attend the same schools. Pollsters no longer bother to ask that question.

Good arguments challenge such findings, but these results were all reported by highly reputable researchers and there is more supporting evidence behind each. The policy question they raise is why, in Richard Kahlenberg's wonderful observation, "today a bipartisan consensus holds that integrated schools are a good thing but we shouldn't do much of anything to promote them" (Kahlenberg 2001, 42). But the political science questions are the focus here: why do many responsible public officials insist that school desegregation has failed, and why do many reputable academics, even those who agree that it has had substantive benefits, also insist on its failure? Why emphasize only one side of a very mixed and complex narrative?

Just as the meaning of "failure" varies with people's political ideology and position, so analytic explanations for their assertion of failure will also vary. Political science is not bereft of tools to analyze the various reasons. Theories of racism presumably provide a psychological explanation for some opponents' views - although none of those quoted above. Skepticism about governmental intervention in private choices (and disregard of the fact that governments are deeply implicated in the racial composition of neighborhoods and school districts) presumably provides an ideological explanation of other opponents' views. Black mayors' desire to retain their constituents might provide a political explanation for elected officials' rejection of further efforts to mix the races. The need to keep ideologically-driven members of an organization motivated might explain liberals' insistence on fiery rhetoric about approaching nightmares (Mansbridge 1986). Black nationalists might reject the apparent insult embedded in the claim that black students need desegregation in order to improve their schooling outcomes. And we must not underestimate the old standby of the issue attention cycle, or the simple fact of disillusionment that follows high hopes only partially realized. ${ }^{5}$

Nevertheless, this set of explanations has an ad hoc quality. Political scientists have not done enough to develop general theories of why most analysts and political actors are so much more likely to emphasize failure than success, despite the mixed evidence in this and other cases and despite the fact that most of us believe that individuals in private life respond more effectively to encouragement than to discouragement. This apparently excessive emphasis on failure holds in other arenas such as environmental policy on the left and fears about the dissolution of the family on the right, so it seems worthy of more sustained attention than we have given it.

\section{The Mismatches of School Vouchers}

As schooling advocates moved away from the "failed" policy of school desegregation, they mainly moved toward two quite different reforms-market-based choice systems or standards-based systemic reform. (Some endorsed both and some neither, but in this brief essay I can only touch 
separately on these two efforts.) Both present fascinating policy issues and either might offer real hope for students and schools that desperately need it. But here I want to look only at the issues that they raise for political science.

Urban school districts, with occasional exceptions in particular schools or along particular substantive dimensions, are largely a disaster. Regardless of whether one sees the cause as too much or too little school desegregation as the cause, or sees it as irrelevant, that view is widely shared-and appropriate. I cannot address here why urban schools are so terrible; suffice it to say that they demonstrate in my view the willingness of a majority of Americans to accept deep racial, ethnic, and class divisions and to deny equality of opportunity to other people's children so that their own children have a better chance of attaining success. ${ }^{6}$ Whatever the reason that urban schools came to be so bad, proponents of vouchers and of systemic reform both believe that their preferred policy offers the best chance to help urban children. But both proposals exhibit strange political conundrums which political scientists could, and should, help illuminate.

Voucher advocates face a mismatch between ideologically committed elites and resistant presumed followers. That is, market-oriented activists (mostly in the Republican party) seek to make public resources available to all parents so that they can choose their child's school, typically including private and parochial schools. The most sophisticated proponents point out that well-off parents already have school choice by virtue of being able to move to a particular district and neighborhood, and argue that all families deserve the same right regardless of income or residence. But key Republican constituents, especially those well-off suburbanites (who are disproportionately Anglo), are not at all enthusiastic about widespread programs of school choice. After all, some inner-city children might seek admission to their schools. Thus when it comes to broad programs involving urban children and movement across district lines, the politics of choice begin to resemble the politics of desegregation; many members of the non-urban middle class profess belief but few are willing to participate in anything more than token numbers. Politicians are well aware of that fact, so the two major private-school choice programs that came into being through legislative action were authorized only within the city limits of Milwaukee and Cleveland. No public schools in suburban districts adjoining Cleveland accepted either the state's invitation or a federal judge's plea to participate.

The irony does not stop here, however. Voucher opponents face an equal but opposite mismatch between ideologically committed elites and resistant presumed followers. That is, advocates of public schooling (mostly in the Democratic party) strongly oppose vouchers, and sometimes also the milder form of school choice entailed in charter schools. But in many surveys, more African Americans, Latinos, the poor, the young, urban residents, and the poorly educated-that is, core Democratic party constituents-endorse voucher proposals at a higher rate than do their respective opposites. In some surveys a majority of one or more of these groups support choice-based policy reforms.

So both parties face a gap between their elites' ideology and their constituents' preferences. What can political science say about this curious phenomenon? Perhaps it is an indicator of a potential party realignment, if that rubric still holds up. ${ }^{7}$ Perhaps it points to broader patterns of mismatch, say between the well-educated, who tend to be relatively liberal on social policies and conservative on economic policies, and the poorly-educated, who tend toward the reverse. ${ }^{8}$ In any case, here is another instance in which political scientists could illuminate the politics of policy advocacy, and thereby be fur- thered in the task of developing theories of political alignment, coalition-building, and political idealogy.

\section{The Political Disincentives for Systemic Reform}

My third and final puzzle arises from the other major policy response to the perceived failure of school desegregation - the 15-year-old effort to create statewide (and perhaps national) curricular standards, and then hold schools, teachers, and students accountable for achieving them through tests. Why would elected officials endorse such a reform, and beg voters to hold them accountable for achieving its goals? ${ }^{9}$

Since the mid-1980s, that is what they have been doing. I have space here for only one representative quotation, from James Hunt, former governor of North Carolina:

In this new era of accountability, candidates will be judged for their education leadership. They must be knowledgeable about the issues and relentless about results. I predict that the avowed education candidates who fail to follow up platitudes with performance, and who fail to match rhetoric with results, won't be around much longer.

Almost every state has established explicit standards in one or more subject areas, and most have set up tests to see if the standards are being met. Failure to pass the tests has severe consequences for either students or teachers in 25 states, and the stringency of standards and their accompanying tests rose during the 1990s. Large majorities of both houses of Congress enthusiastically passed the "No Child Left Behind" law (NCLB) early in 2002; it imposes a strict testing regime with considerable penalties for failure, and the district-level threshhold for passing is mandated to rise each year for the next decade.

Political science gives us few theories to explain why these changes have occurred; in fact, it is much better at explaining why they should not have done so. Citizens were not clamoring for higher standards; for 30 years, survey respondents have given the nation's schools an average grade of $\mathrm{C}$ and their own child's school an average grade of B. These are not stellar grades, but they have remained stable so they cannot explain the changing policy. When asked about problems in the schools, respondents are always much more concerned about discipline, drugs, and violence than about low standards, insufficient achievement, or the quality of teaching. In fact until recently, Americans were more likely to complain about too much curricular innovation and too much focus on grades than about too little. The most substantial public opposition to the new regime of standards and testing has arisen in politicallypowerful suburban districts (where it is likely to have the least impact). So citizen demand, either in general or in strategically located constituencies, does not explain this sweeping reform.

Neither does interest group pressure. Educators were among the last to endorse the movement toward standards and testing, and many powerful educational interest groups still oppose it or are deeply skeptical. Business leaders were at the forefront of the standards movement - itself a historical oddity that needs explanation.

Nor can systemic reform be explained as a rational response to a widely-recognized crisis. Inner city schools are indeed in a crisis, and arguably getting worse. Other schools are not in a crisis; over the past few decades, they have done worse by some measures, better by others. The standards movement, however, does not target resources, energy, penalties, or incentives on urban schools and districts. If policy-makers were 
really committed to leaving no child behind, new state and federal laws would devote tremendous attention to the schools in the 100 largest cities (and a few rural areas), and leave the rest to muddle along. They do not.

Most significantly from a political science perspective, scholars have argued for decades that the last thing any elected official wants is to be held electorally accountable for achieving a particular outcome at a given moment, especially when that outcome is extremely difficult to accomplish and its accomplishment lies in the hands of a notoriously loosely-coupled entity such as the public school system. ${ }^{10}$ Furthermore, as Douglas Arnold has shown (1990), politicians usually design laws and policies so that they cannot be held accountable if the law imposes high costs (such as failure to graduate) on identifiable constituents (such as the parents of a failing student). Why, in any case, would Democratic members of Congress and state legislatures promulgate a policy that teachers' unions hate, and why would Republican members of Congress and a conservative Republican president promote a law (NCLB) to enhance the federal role in education, and to prod schools into helping poor, black, and immigrant children-not exactly Republican constituents?

Perhaps the whole decade and a half of reform has been nothing but smoke and mirrors: Republicans are pretending to be compassionate in order to be conservative, and Democrats are pretending to be tough-minded in order to be tenderhearted. And members of both parties are pretending to believe the other, and trusting that voters will not see through the ruse. Conversely, perhaps Republican politicians genuinely believe that the threat of test failure will give administrators, teachers,

\section{Notes}

1. Unless otherwise noted, facts, quotations, and arguments in this article come from my co-authored book, Hochschild and Scovronick 2003.

My thanks to Nate Scovronick for our many years of working together on this project. He is not responsible for anything in this essay.

2. Those that have $90 \%$ or more non-Anglo students.

3. Data in this paragraph are from Frankenberg et al. 2003. All of these changes must be seen in light of our nation's changing demography. From 1968 to 2000, the number of Latino public school students grew from 2 to 7.7 million, Anglo students declined from 34.7 to 28.8 million, and black students increased from 6.3 to 8.1 million. The number of Asian students also increased to almost 2 million. So there are absolutely fewer, and relatively many fewer, Anglo students with whom to desegregate.

4. In addition to the material cited in Hochschild and Scovronick 2003, see Quillian and Campbell 2003.

5. Pride 2000 offers an interesting case study of the politics of misperceptions of desegregative failure.

\section{References}

Armor, David. 1995. Forced Justice: School Desegregation and the Law. New York: Oxford University Press.

Arnold, R. Douglas. 1990. The Logic of Congressional Action. New Haven: Yale University Press.

Baumgartner, Frank, and Bryan Jones. 1993. Agendas and Instability in American Politics. Chicago: University of Chicago Press.

Frankenberg, Erica, et al. 2003. A Multiracial Society with Segregated Schools: Are We Losing the Dream? Harvard University: The Civil Rights Project.

Gilens, Martin. 2003. "Public Opinion and Democratic Responsiveness: Who Gets What They Want from Government?" Inequality and American Democracy. Princeton NJ.

Guryan, Jonathan. 2001. Desegregation and Black Dropout Rates. National Bureau of Economic Research, WP 8345.

Hochschild, Jennifer. 2003. "Rethinking Accountability Politics" In No Child Left Behind? The Politics and Practice of School Accountability, and students enough of an incentive to pull their socks up and really get to work-or NCLB is a Trojan horse for vouchers, as some believe (but see the second puzzle, above). Or perhaps Democratic politicians genuinely believe that Republicans will, this time, provide the financial resources needed to improve abysmal and deeply poor schools, despite the fact that they lie mainly in cities full of Democratic voters. Whatever the explanation for the bipartisan movement toward standardsbased reform with high-stakes tests, it stands badly in need of some careful analysis by sophisticated political scientists.

Here too, this particular case opens wider arenas. When and why do politicians behave unexpectedly — such as by insisting that they be held accountable for very difficult measured outcomes, or by allying with members of the other party against the preferences of their own powerful constituency groups (in this case, teachers' unions and suburban parents for Democrats and Republicans respectively)? Perhaps theories of agenda setting or issue evolution would be helpful here (Stone et al. 2001; Baumgartner and Jones 1993). Perhaps theories of federalism could explain when governors, legislators, and mayors seek to become involved in an issue that they have struggled for a century to avoid. Perhaps demography is, eventually, destiny-and politicians of all stripes concur that they must make policies to incorporate the rising number of immigrants. ${ }^{11}$ Perhaps theories of Congressional decision-making, or of presidential manipulation of public opinion, are relevant. In any case, the subject of school desegregation and its complicated aftermath warrants much more attention from our discipline, even among those for whom the particular policy issues are not of special interest.
6. As with most other claims in this essay, this large argument is explicated and defended in Hochschild and Scovronick, The American Dream and the Public Schools.

7. For a powerful attack on the concept and operationalization of party realignment, see Mayhew 2002.

8. Gilens 2003 demonstrates this pattern in an analysis of 754 national survey questions asked from 1992 through 1998.

9. The arguments and evidence in this section are drawn from Hochschild 2003.

10. As a politically savvy economist once put it, no successful politician can be pinned down to give a number and a date at the same time.

11. Immigration policy itself raises another fascinating political puzzlehas any nation ever before passed laws by which the dominant racial or ethnic majority willed itself to become a minority of the population within the foreseeable future? eds. Paul Peterson and Martin. West. Washington, D.C.: Brookings Institution.

Hochschild, Jennifer, and Nathan Scovronick. 2003. The American Dream and the Public Schools. New York: Oxford University Press.

Kahlenberg, Richard. 2001. "The Fall and Rise of School Segregation." American Prospect 12(9):41-43.

Mansbridge, Jane. 1986. Why We Lost the ERA. Chicago: University of Chicago Press.

Mayhew, David. 2002. Electoral Realignments: A Critique of an American Genre. New Haven: Yale University Press.

Phillips, Meredith. 1998. "Do African American and Latino Children Learn More in Predominantly White Schools?" Los Angeles: UCLA, Department of Policy Studies.

Pride, Richard. 2000. "Public Opinion and the End of Busing: (Mis)perceptions of Policy Failure." Sociological Quarterly 41(2): $207-25$. 
Quillian, Lincoln, and Mary Campbell. 2003. "Beyond Black and White: The Present and Future of Multiracial Friendship Segregation." American Sociological Review 68(4):540-66.
Stone, Clarence, et al. 2001. Building Civic Capacity: The Politics of Reforming Urban Schools. Lawrence: University Press of Kansas. 